\title{
My Dear English Teacher
}

\section{Lina María Calixto}

Many ineffable virtues you have showed me, since

You have encouraged me to live without fear.

Day after day, you have inspired me with

Each of your smiles, which seems like a flash full of strength.

A wave of knowledge is in your ocean of words.

Real talent of hope, you emanate.

Educating with love is your passion.

Nest of dreams, you instill.

Gentle, seemly, unique... perfect you are to me.

Lake of feelings, you emerge.

If I were you; I would also change worlds.

Soul that appeases uneasy beings.

Heart that teaches, spirit that sings.

Today, I want to make a confession.

English is wonderful with you.

And each English class becomes a new way to feel happiness.

Could I tell you a deep secret?

Half of me, I owe it to you.

Every day, I want to be like you, a

Ray that reflects a dazzling English teacher. 